\title{
A Shot in the Dark! RAAS Inhibitors Cause Severe COVID-19 Infection
}

\author{
Bhuvana Krishna®
}

Indian Journal of Critical Care Medicine (2021): 10.5005/jp-journals-10071-23796

Coronavirus disease-2019 (COVID-19) pandemic caused by severe acute respiratory syndrome coronavirus- 2 (SARS-CoV-2), which started in Wuhan in Hubei Province of China in December 2019, has spread to all parts of the globe and continues to be a major global health concern. ${ }^{1}$ The SARS-CoV-2 enters human cells after binding of the viral spike protein to the angiotensin-converting enzyme receptor-2(ACE2) expressed on the host alveolar cells. ${ }^{2}$

Homologue of the ACE1 receptor but with divergent physiological functions. ACE1 receptor is expressed in all tissues and is an upregulator of the renin-aldosterone-angiotensin system (RAAS). It converts angiotensin I to the vasoactive angiotensin II molecule. ACE2 is expressed on alveolar epithelial cells and endothelial cells and counterbalances the effect of ACE1. This enzyme converts angiotensin II to angiotensin (1-7) molecule, which has vasodilatory, anti-inflammatory, and cardioprotective properties. $^{3}$

ACE inhibitors and angiotensin receptor blockers (RAAS inhibitors) are the drugs commonly used in treating cardiovascular diseases. It was inferred from animal studies that the use of these drugs increases the expression of ACE2 receptors and hence may increase SARS-CoV-2 entry into the human cells causing severe infection. ${ }^{4}$ The evidence from human studies do not support the hypothesis that RAAS inhibitors increase the expression of ACE2 receptors. ${ }^{5}$

The conflicting evidence and initial studies from Wuhan, China reporting severe SARS-CoV-2 infection in patients with underlying hypertension and cardiovascular disease, had raised concerns among health professionals and patients on the safety in continuing RAAS inhibitors during this pandemic. ${ }^{6}$ This confusion was further fueled by information from the media, leading to a change in the prescription of these medications. RAAS inhibitors are medications proven to have a mortality benefit in patients with heart failure and other cardiovascular diseases. Stoppage of RAAS inhibitors in these patients would have been detrimental.

Conversely, the ACE2 enzyme is necessary for the amelioration of lung inflammation through angiotensin (1-7) molecule. RAAS inhibitors may be useful in cardiac injury induced by COVID-19 infection. ${ }^{7}$ Quick research was needed to support or prove the contrary that RAAS inhibitors predispose people to severe COVID-19 infection.

Pooled meta-analysis to date has shown no association between RAAS inhibitors and COVID-19 related outcome. ${ }^{8-10}$ There is no data from India to date to study this relationship. One retrospective study by Reddy et al. ${ }^{11}$ substantiates the evidence that the use of RAAS inhibitors is safe during the current COVID-19 pandemic.
Department of Critical Care Medicine, St. John's Medical College and Hospital, Bengaluru, Karnataka, India

Corresponding Author: Bhuvana Krishna, Department of Critical Care Medicine, St John's Medical College and Hospital, Bengaluru, Karnataka, India, Phone: +91 9945693221, e-mail: bhuvana.11@gmail.com

How to cite this article: Krishna B. A Shot in the Dark! RAAS Inhibitors Cause Severe COVID-19 Infection. Indian J Crit Care Med 2021;25(4):353-354.

Source of support: Nil

Conflict of interest: None

Ideally larger randomized controlled trials are necessary to study the causal relationship between RAAS inhibitors and COVID-19 infection-benefit, harm, or no association.

\section{OrCID}

Bhuvana Krishna 구 http://orcid.org/0000-0002-0003-6797

\section{References}

1. World Health Organization. COVID-19 weekly epidemiological update, 2 February 2021.

2. Hoffmann M, Kleine-Weber H, Schroeder S, Krüger N, Herrler T, Erichsen S, et al. SARS-CoV-2 cell entry depends on ACE2 and TMPRSS2 and is blocked by a clinically proven protease inhibitor. Cell 2020;181(2):271-280. DOI: 10.1016/j.cell.2020.02.052.

3. Tikellis $C$, Thomas MC. Angiotensin-converting enzyme 2 (ACE2) is a key modulator of the renin-angiotensin system in health and disease. Int J Pept 2012;2012:256294. DOI: 10.1155/2012/256294.

4. Ferrario CM, Jessup J, Chappell MC, Averill DB, Brosnihan KB, Tallant $E A$, et al. Effect of angiotensin-converting enzyme inhibition and angiotensin II receptor blockers on cardiac angiotensin-converting enzyme 2. Circulation 2005;111(20):2605-2610. DOI: 10.1161/ CIRCULATIONAHA.104.510461.

5. Sriram K, Insel PA. Risks of ACE inhibitor and ARB usage in COVID-19: evaluating the evidence. Clin Pharmacol 2020;108(2):236-241. DOI: 10.1002/cpt.1863.

6. Wu C, Chen X, Cai Y, Zhou X, Xu S, Huang H, et al. Risk factors associated with acute respiratory distress syndrome and death in patients with coronavirus disease 2019 pneumonia in Wuhan, China. JAMA Intern Med 2020;180(7):934-943. DOI: 10.1001/jamainternmed.2020.0994.

7. Wang JJ, Edin ML, Zeldin DC, Li C, Wang DW, Chen C. Good or bad: application of RAAS inhibitors in COVID-19 patients with cardiovascular comorbidities. Pharmacol Ther 2020;215:107628. DOI: 10.1016/j.pharmthera.2020.107628.

(0) Jaypee Brothers Medical Publishers. 2021 Open Access This article is distributed under the terms of the Creative Commons Attribution 4.0 International License (https://creativecommons.org/licenses/by-nc/4.0/), which permits unrestricted use, distribution, and non-commercial reproduction in any medium, provided you give appropriate credit to the original author(s) and the source, provide a link to the Creative Commons license, and indicate if changes were made. The Creative Commons Public Domain Dedication waiver (http://creativecommons.org/publicdomain/zero/1.0/) applies to the data made available in this article, unless otherwise stated. 
8. Grover A, Oberoi M. A systematic review to evaluate the clinical outcomes in COVID-19 patients on angiotensin-converting enzyme inhibitors or angiotensin receptor blockers. MedRxiv 2020. DOI: 10.1101/2020.04.29.20085787.

9. Mackey K, King VJ, Gurley S, Kiefer M, Liederbauer E, Vela K, et al. Risks and impact of angiotensin-converting enzyme inhibitors or angiotensinreceptor blockers on SARS-CoV-2 infection in adults: a living systematic review. Ann Intern Med 2020;173(3):195-203. DOI: 10.7326/M20-1515.
10. Kurdi A, Abutheraa N, Akil L, Godman B. A systematic review and meta-analysis of the use of renin-angiotensin system drugs and COVID-19 clinical outcomes: what is the evidence so far? Pharmacol Res Perspect 2020;8(6):e00666. DOI: 10.1002/prp2.666.

11. Reddy PR, Samavedam S, Aluru N, Rajyalakshmi B. Comparison of severity of COVID-19 infection among patients using RAAS inhibitors and non-RAAS inhibitors. Indian J Crit Care Med 2021;25(4): 366-368. 